\title{
Interactive comment on "Data assimilation of sea surface temperature and salinity using basin-scale EOF reconstruction: a feasibility study in the NE Baltic Sea" by Mihhail Zujev et al.
}

\section{Anonymous Referee \#3}

Received and published: 16 July 2020

The comment was uploaded in the form of a supplement:

https://os.copernicus.org/preprints/os-2020-43/os-2020-43-RC3-supplement.pdf

Interactive comment on Ocean Sci. Discuss., https://doi.org/10.5194/os-2020-43, 2020. 